\title{
Pioglitazone time-dependently reduces tumour necrosis factor- $\alpha$ level in muscle and improves metabolic abnormalities in Wistar fatty rats
}

\author{
K. Murase, H. Odaka, M. Suzuki, N. Tayuki, H. Ikeda \\ Pharmaceutical Research Laboratories I, Takeda Chemical Industries, Osaka, Japan
}

\begin{abstract}
Summary In order to evaluate the relationship between tumour necrosis factor- $\alpha$ (TNF- $\alpha$ ) level in muscle and metabolic abnormalities in obesity and diabetes mellitus, pioglitazone, a novel insulin-sensitizing agent, was administered to Wistar fatty rats and time-dependent changes in muscle TNF- $\alpha$ content and plasma indicators of diabetes and obesity were measured. Wistar fatty rats were hyperglycaemic, hyperlipidaemic and hyperinsulinaemic, and their plasma and muscle TNF- $\alpha$ levels were two or more times higher than those in normal lean rats at 16 weeks of age. When pioglitazone was administered to fatty rats at a dose of $3 \mathrm{mg} \cdot \mathrm{kg}^{-1} \cdot$ day $^{-1}$, the plasma triglyceride level and TNF- $\alpha$ levels in plasma and muscle decreased time-dependently, and reached the levels of lean rats within 4 days. Plasma glucose and insulin levels also decreased time-dependently with pioglitazone, but on day 4,
\end{abstract}

these levels were still much higher than the levels in lean rats. Neutral sphingomyelinase (SMase) activity in muscle of fatty rats was two times higher than that in lean rats and was lowered to the level of that in lean rats by 4 days' pioglitazone administration. The plasma leptin level in fatty rats was 8 times higher than that in lean rats, but pioglitazone did not affect the level during the 4-day administration period. These results suggest that an increase in TNF- $\alpha$ production and subsequent activation of SMase in muscle leads to metabolic abnormalities in obesity and diabetes and that antidiabetic activity of pioglitazone is deeply associated with the suppression of TNF- $\alpha$ production. [Diabetologia (1998) 41: 257-264]

Keywords Pioglitazone, muscle TNF- $\alpha$, sphingomyelinase, insulin resistance, Wistar fatty rat.
Metabolic abnormalities in obesity and non-insulindependent diabetes mellitus (NIDDM) are linked to insulin resistance [1-4]. Although the mechanism for the development of insulin resistance has not been fully clarified, recent studies imply a correlation between tumour necrosis factor- $\alpha$ (TNF- $\alpha$ ) and insulin

Received: 29 August 1997 and in revised form: 13 October 1997

Corresponding author: Dr. K. Murase, Pharmaceutical Research Laboratories I, Takeda Chemical Industries, Ltd., 2-17 Juso-honmachi, Yodogawa-ku, Osaka 532, Japan

Abbreviations: TNF- $\alpha$, Tumour necrosis factor- $\alpha$; SMase, sphingomyelinase; NIDDM, non-insulin-dependent diabetes mellitus; IRS-1, insulin-receptor substrate-1; IR, insulin receptor; MAPK, mitogen-activated protein kinase; EIA, enzyme immunoassay; PI3, phosphatidylinositol 3. resistance. These studies demonstrated that TNF- $\alpha$ mRNA expression is increased in adipose tissue of obese animals [4-6] and humans [7, 8], that infusion of TNF- $\alpha$ into rats results in insulin resistance in muscle [9] and that neutralization of TNF- $\alpha$ by infusion of TNF- $\alpha$ receptor-IgG chimeric protein into obese rats increases peripheral glucose uptake in response to insulin [4]. It was also shown that TNF- $\alpha$ mRNA is overexpressed in muscle of diabetic patients [10] and that the RNA transcript encoding the p55 TNF- $\alpha$ receptor is elevated in muscle of genetically obese and diabetic $\mathrm{KKA}^{\mathrm{y}}$ mice [11]. Since the half-life of TNF- $\alpha$ in blood is very short and muscle plays a principal role in inducing impaired glucose metabolism in insulin resistance [12], it is supposed that TNF- $\alpha$ produced in muscle acts in an autocrine fashion or that produced in adipose tissue works on the adjoining muscle. 


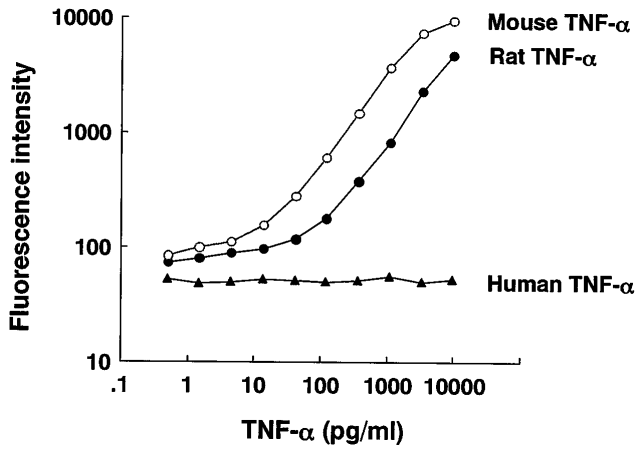

Fig. 1. Standard curves for mouse TNF- $\alpha$, rat TNF- $\alpha$, and human TNF- $\alpha$ obtained using a two-site EIA system

The intracellular mechanism for TNF- $\alpha$-induced insulin resistance has been somewhat clarified. TNF- $\alpha$ inhibits insulin signalling by binding the p55 TNF- $\alpha$ receptor and the subsequent activation of neutral sphingomyelinase (SMase) [13]. TNF- $\alpha$ responsive neutral SMase hydrolyses membrane sphingomyelin to ceramide which activates membrane-bound ceramide-activated protein kinase [14], and the kinase probably induces serine phosphorylation of insulin receptor substrate-1 (IRS-1) and converts IRS-1 into an inhibitor of insulin receptor (IR) tyrosine kinase activity [15].

The insulin-sensitizing agent pioglitazone has been shown to improve hyperglycaemia, hyperlipidaemia and hyperinsulinaemia by reduction of peripheral insulin resistance in obese and diabetic animals [16-20]. In order to elucidate the relationship between the muscle TNF- $\alpha$ level and insulin resistance, we administered pioglitazone to genetically obese and diabetic Wistar fatty rats and compared the time-course of changes in the muscle TNF- $\alpha$ level and plasma indicators of obesity and diabetes.

\section{Materials and methods}

Animals and drugs. Wistar fatty rats and their lean littermates (16-week-old; male) were obtained from the Laboratory Animal Unit of our company and maintained on a laboratory chow diet (CE-2; Clea, Tokyo, Japan). They were housed in individual metal cages in a room with controlled temperature $\left(23 \pm 1{ }^{\circ} \mathrm{C}\right)$, humidity $(55 \pm 5 \%)$ and lighting (08.00 20.00 hours). At the age of 16 weeks, male Wistar fatty rats were divided into 5 groups (10 rats each) based on body weight and plasma components, and the rats in 4 groups were given pioglitazone $\cdot \mathrm{HCl}$ (pioglitazone, synthesized in our company) suspended in a $0.5 \%(\mathrm{w} / \mathrm{v})$ methylcellulose solution orally (via a stomach tube) at a dose of $3 \mathrm{mg} \cdot \mathrm{kg}^{-1} \cdot \mathrm{day}^{-1}$. Before and after 1, 2, 3 and 4 days of pioglitazone treatment, rats were killed by exsanguination between 09.00 and 10.00 hours. Because diabetic states (hyperglycaemia, hypertriglyceridaemia, hyperinsulinaemia, etc) in fatty rats are stable, nontreated fatty rats ( 0 day) were used as fatty controls. Non-treated age-matched lean rats were used as normal controls.
Plasma components. Plasma glucose and triglyceride concentrations were determined using commercially available assay kits (Iatron, Tokyo, Japan), and plasma immunoreactive insulin concentration was determined using a radioimmunoassay kit (Shionogi, Osaka, Japan). Plasma leptin concentration was determined using a radioimmunoassay kit for mouse leptin (Linco Research Inc.; St. Charies, Missouri, USA) with recombinant rat leptin as the standard.

$T N F-\alpha$ assay. Recombinant mouse and rat TNF- $\alpha$ were purchased from Serotec Ltd (Oxford, UK). The polyclonal antiserum against mouse TNF- $\alpha$ was purchased from Genzyme (Cambridge, Mass., USA).

The skeletal muscle was frozen on dry ice and stored at $-80^{\circ} \mathrm{C}$. The samples were sonicated in cold $0.1 \mathrm{~mol} / \mathrm{l}$ Tris- $\mathrm{HCl}$ buffer, $\mathrm{pH} 7.6$, containing $1 \mathrm{~mol} / 1 \mathrm{NaCl}, 2 \%$ bovine serum albumin (BSA), $2 \mathrm{mmol} / \mathrm{l}$ ethylenediamine tetraacetic acid (disodium salt), 80 trypsin-inhibitory units of aprotinin/liter and $0.02 \% \mathrm{NaN}_{3}$ (Buffer A) at $5 \%$ wet tissue weight per volume. The solution was centrifuged at $14000 \mathrm{rev} / \mathrm{min}$ for $30 \mathrm{~min}$, and the supernatant obtained was examined for TNF- $\alpha$ content.

Five microliters of anti-TNF- $\alpha$ polyclonal $\mathrm{IgG}(100 \mu \mathrm{g} / \mathrm{ml}$ in $0.1 \mathrm{~mol} / 1$ Tris- $\mathrm{HCl}$ buffer, $\mathrm{pH} 8.0$ ) was added to the wells of polystyrene microtiter plates (Falcon, Lincon Park, N.J., USA), and the plates were incubated for $2 \mathrm{~h}$ at room temperature. Excess IgG solution was removed from the wells, and the plates were then washed twice with $0.1 \mathrm{~mol} / 1$ Tris- $\mathrm{HCl}$ buffer (pH 7.6) containing $0.4 \mathrm{~mol} / 1 \mathrm{NaCl}, 0.1 \% \mathrm{BSA}, 0.1 \% \mathrm{NaN}_{3}$ and $1 \mathrm{mmol} / 1 \mathrm{MgCl}_{2}$ (buffer W). Aliquots of standard TNF- $\alpha$ or sample $(10 \mu \mathrm{l})$ were added to the wells, and the plates were incubated for $2.5 \mathrm{~h}$ at room temperature. Each well was washed three times with buffer $\mathrm{W}$, and $20 \mu \mathrm{l}$ of biotinylated antiTNF- $\alpha$ antibody IgG solution ( $35 \mathrm{ng} / \mathrm{ml}$ in buffer $\mathrm{W}$ ) was added. Biotinylated conjugates of anti-TNF- $\alpha$ antibody were prepared by the method published earlier [21]. Incubation was carried out overnight at $4^{\circ} \mathrm{C}$. Each well was then washed three times with buffer $\mathrm{W}$, and $20 \mu \mathrm{l}$ of streptavidin-linked $\beta$-D-galactosidase (Boehringer Mannheim GmbH, Mannheim, Germany), (diluted 6000 fold with buffer W) was added. After incubating for $1 \mathrm{~h}$ at room temperature, each well was washed three times, and $\beta$-D-galactosidase activity was then assayed. The enzyme reaction was started by the addition of $30 \mu \mathrm{l}$ of buffer $\mathrm{W}$ containing $60 \mathrm{mmol} / 1$ 4-methylumbelliferyl- $\beta$-D-galactoside (Sigma, St.Louis, Mo., USA). After incubating for $4 \mathrm{~h}$ at room temperature, the enzyme reaction was stopped by the addition of $0.13 \mathrm{ml}$ of $0.1 \mathrm{~mol} / \mathrm{l}$ glycine- $\mathrm{NaOH}$ buffer $(\mathrm{pH}$ 10.3). The amount of 4-methylumbelliferone formed was measured with a fluorescence spectrometer (CytoFluor II; PerSeptive Biosystems, Framingham, Mass., USA) set at wavelengths of 350 and $460 \mathrm{~nm}$ for excitation and emission, respectively.

Neutral SMase assay. Trinitrophenylaminolauroyl-sphingomyelin (TNPAL-SM) and neutral sphingomyelinase were purchased from Sigma.

The neutral SMase assay using TNPAL-SM was performed according to a method described by Gatt et al. [22] with some modification. Skeletal muscles were homogenized in cold $0.05 \mathrm{~mol} / \mathrm{l}$ Tris- $\mathrm{HCl}$ buffer, $\mathrm{pH} 7.4$, containing $0.1 \%$ Triton X100 and $0.02 \mathrm{~mol} / 1 \mathrm{MgCl}_{2}$ (Buffer B) at $5 \%$ wet tissue weight per volume. The solution was centrifuged at $14000 \mathrm{rev} / \mathrm{min}$ for $30 \mathrm{~min}$, and the supernatant obtained was examined using for neutral SMase activity. The protein concentration in supernatants was determined by the Bradford assay (Bio Rad, Hercules, Calif., USA). Incubation mixtures containing $20 \mu \mathrm{l}$ $(22.2 \mu \mathrm{g})$ of TNPAL-SM, $50 \mu \mathrm{l}$ of buffer B and $150 \mu \mathrm{l}$ of assay sample were incubated for $15 \mathrm{~min}$ at $37^{\circ} \mathrm{C}$. The reaction was 

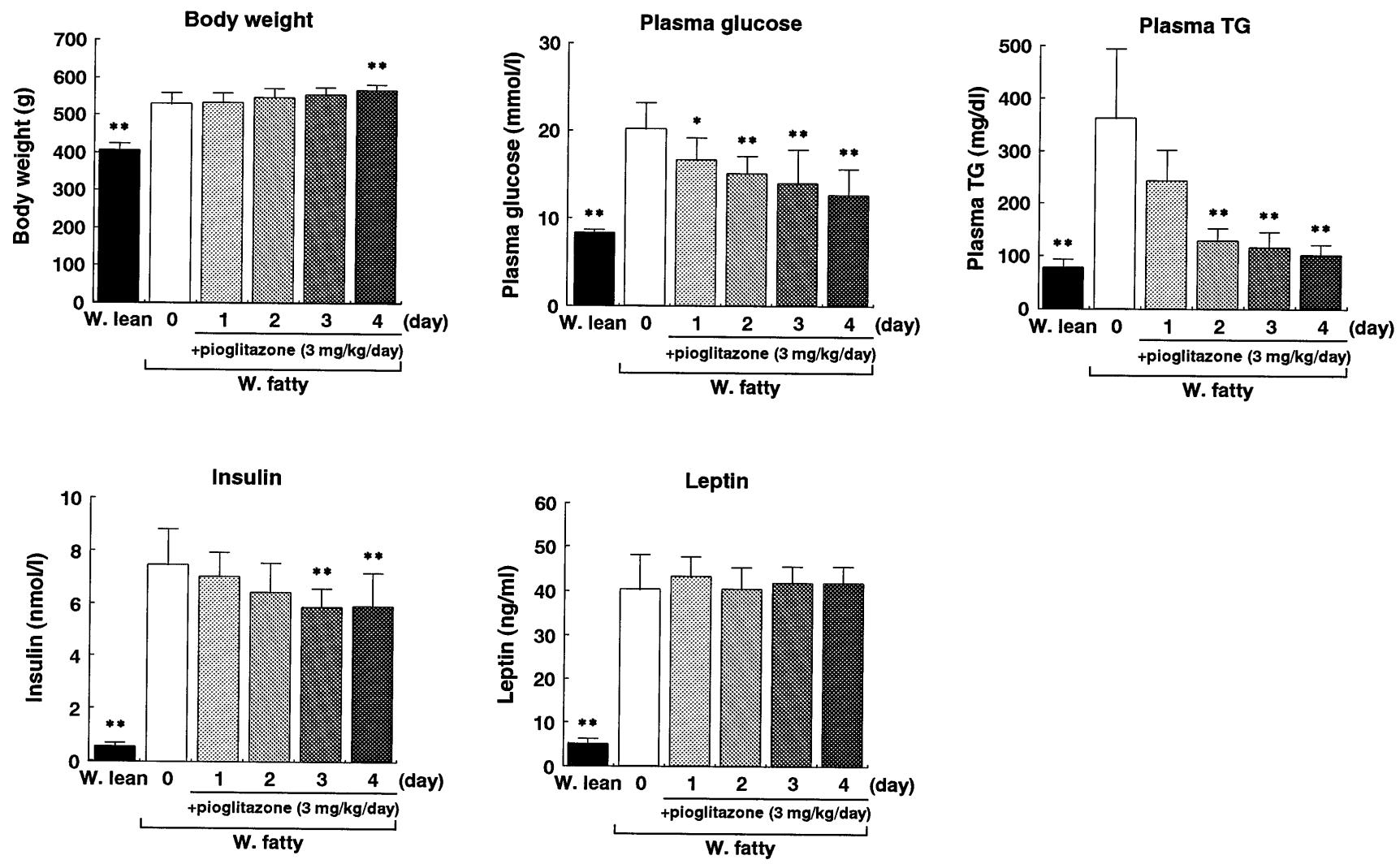

Fig. 2. Effects of pioglitazone on plasma component levels in Wistar fatty rats. Pioglitazone was administered orally to 16week-old male Wistar fatty rats $(3 \mathrm{mg} / \mathrm{kg})$ for $1-4$ days, as described in Methods. Data are mean \pm SD $(n=10) .{ }^{*} p<0.05$ and $* * p<0.01$ vs non-treated Wistar fatty rats

terminated by adding $750 \mu \mathrm{l}$ of isopropanol/heptane $/ 5 \mathrm{~mol} / \mathrm{l}$ $\mathrm{H}_{2} \mathrm{SO}_{4}(40: 10: 1, \mathrm{v} / \mathrm{v})$. The tubes were shaken, and $400 \mu \mathrm{l}$ of water and $400 \mu \mathrm{l}$ of heptane were added. The tubes were shaken for $5 \mathrm{~min}$ and then centrifuged for $5 \mathrm{~min}$ at $3000 \mathrm{rev} / \mathrm{min}$. The absorbance of the upper, heptane-rich, phase at $330 \mathrm{~nm}$ was then determined. Activities were determined using a standard curve which was constructed using the same assay method and exogenous neutral SMase. Each value indicates the $\mathrm{mU}$ activity per $g$ protein.

Statistical analysis. Data are expressed as mean \pm SD. Differences of means between the fatty rat control group and other groups were statistically analysed using Dunnett's test. Differences of means between the Wistar lean group and the fatty rat control group were statistically analysed by Student's $t$ test. Regression analysis was performed using data on muscle TNF- $\alpha$ levels and plasma triglyceride or glucose levels in fatty rats obtained at each measurement point.

\section{Results}

Establishment of enzyme immunoassay for TNF- $\alpha$. Each well of a 96-well microtiter plate was coated with polyclonal antibody and TNF- $\alpha$ was sandwiched between this immobile antibody and a secondary biotinylated antibody. This immune complex was then detected with streptavidin linked $\beta$-galactosidase. A typical dose-response curve for TNF- $\alpha$ is shown in Figure 1 (background was not reduced). Rat and mouse TNF$\alpha$ could be determined at concentrations between 1.0 $\mathrm{pg} / \mathrm{ml}$ and $10 \mathrm{ng} / \mathrm{ml}$. This EIA system does not crossreact with human TNF- $\alpha$ owing to the amino acid homology between rat TNF- $\alpha$ and mouse ( $96 \%$ )/human $(84 \%)$ TNF- $\alpha$. By taking into account the TNF- $\alpha$ level in vivo and in vitro, we can use this EIA system for measurement of rat and mouse TNF- $\alpha$.

Changes in muscle TNF- $\alpha$ level and plasma components. When pioglitazone was given to Wistar fatty rats, changes in body weight and plasma components were measured (Fig.2). Fatty rats were $100 \mathrm{~g}$ or more heavier than lean rats, and we observed slight and time-dependent increases in body weight during the 4-day experimental period. This increase was probably due to the enhancement of anabolic actions of insulin. Plasma glucose, triglyceride and insulin levels in fatty rats were 2.4, 4.7 and 12.9 times higher than the levels in lean rats, respectively. Pioglitazone time-dependently decreased these elevated plasma levels. Although the plasma triglyceride level had decreased to the level in lean rats within 2 or 3 days, plasma glucose and insulin levels were higher than the levels in lean rats even after 4 days of pioglitazone treatment. Pioglitazone $\left(3 \mathrm{mg} \cdot \mathrm{kg}^{-1} \cdot\right.$ day $\left.^{-1}\right)$ clearly reduced hyperglycaemia in Wistar fatty rats 


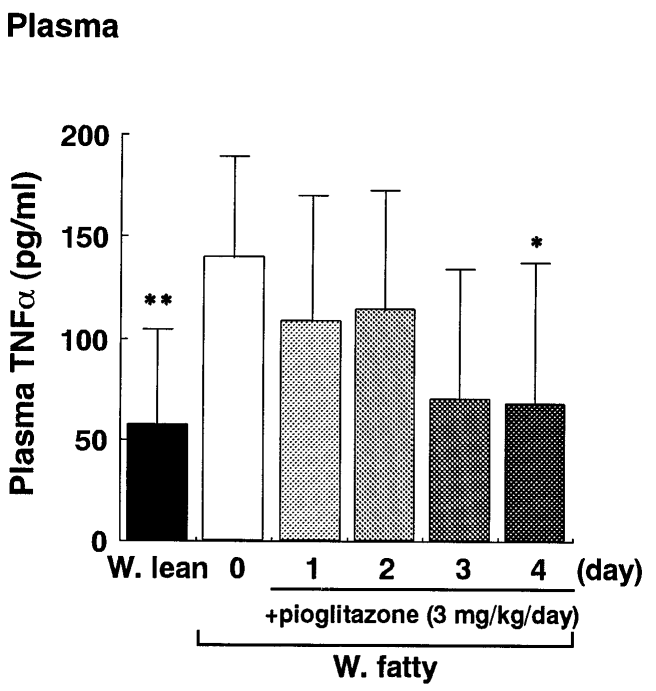

Fig. 3. Effect of pioglitazone on TNF- $\alpha$ levels in plasma and muscle of Wistar fatty rats. Pioglitazone was administered orally to 16 -week-old male Wistar fatty rats $(3 \mathrm{mg} / \mathrm{kg})$ for $1-4$ days, as described in Methods. Data are mean \pm SD $(n=9,10)$. $* p<0.05$ and $* * p<0.01$ vs non-treated Wistar fatty rats

after 6-days administration [19]. The plasma leptin level in Wistar fatty rats was 8.0 times higher than that in lean rats, but 4 days of pioglitazone treatment had no effect on this level.

TNF- $\alpha$ levels in plasma and muscle of fatty rats were 2.5 and 2.3 times higher than the levels of lean rats, respectively, and were time-dependently decreased by pioglitazone (Fig. 3). Comparing with time-dependent decrease of plasma glucose level, the decrease of muscle TNF- $\alpha$ level was faster. The muscle TNF- $\alpha$ level in fatty rats decreased to the level in lean rats after 1 or 2 days of the pioglitazone treatment, as compared with the plasma TNF- $\alpha$ level which fell to the lean level after 3 or 4 days of treatment. In pioglitazone-treated fatty rats and nontreated controls, the correlation between the muscle TNF- $\alpha$ level and the plasma glucose or triglyceride level was examined (Fig. 4). Each point in the figure represents the mean $\pm \mathrm{SD}$ for each experimental group, and the regression lines were drawn using data from fatty rats. There was significant positive correlation between the muscle TNF- $\alpha$ level and the plasma glucose or triglyceride level among the fatty rat groups. Mean \pm SD levels of TNF- $\alpha$ and triglyceride in lean rats fell closer to the regression line than those of TNF- $\alpha$ and glucose.

Changes in neutral SMase activity. Muscle neutral SMase activity was measured in lean and fatty rats and in fatty rats treated with pioglitazone for 4 days (Fig. 5). The neutral sphingomyelinase activity in Wistar fatty rats was two times higher than that in lean

\section{Muscle}

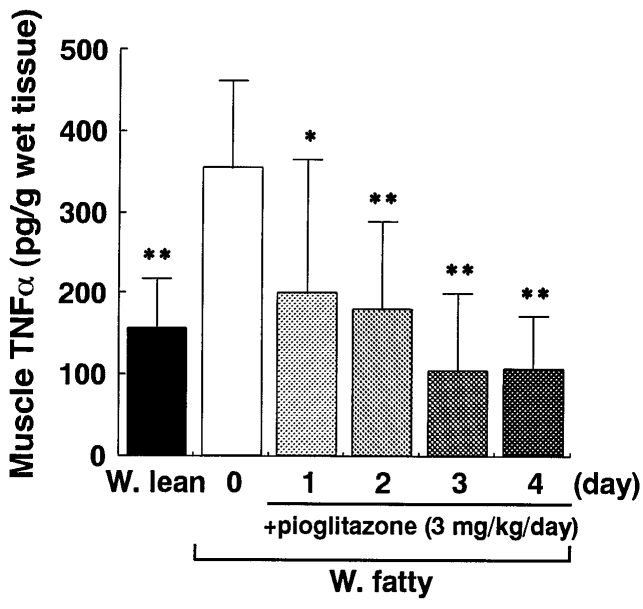

rats. Pioglitazone administration for 4 days decreased the activity to the level in lean rats.

\section{Discussion}

Recent studies using the measurement of TNF- $\alpha$ mRNA levels in adipose tissue and muscle have revealed that TNF- $\alpha$ plays a pivotal role in the development of insulin resistance. Expression of TNF- $\alpha$ mRNA in adipose tissue or muscle is high in insulin resistant obese and/or diabetic patients [7, 8, 10]. Some of these studies showed an inverse correlation between the degree of TNF- $\alpha$ mRNA expression and the glucose clearance rate. Elevated expression of TNF- $\alpha$ mRNA in adipose tissue has also been implicated in animal models of obesity and diabetes [46]. These observations raise the possibility that TNF$\alpha$ might be involved in the mechanism of the onset of NIDDM. However, it is not clear whether TNF- $\alpha$ protein content is closely correlated with TNF- $\alpha$ mRNA level in these tissues or not. In general, protein production from mRNA is introduced by many processes, including translation and proteolytic processing, and thus it depends not only on gene expression but also on subsequent cellular events. Therefore, it is essential to measure TNF- $\alpha$ level instead of the expression of TNF- $\alpha$ mRNA for confirming the contribution of TNF- $\alpha$ to the onset of insulin resistance.

Concentrations of TNF- $\alpha$ protein can be estimated with a biological assay technique using L929 cells or a commercially available EIA kit. However, these assays are used for the measurement of the TNF- $\alpha$ level in serum [23], and are not sensitive enough to measure rat TNF- $\alpha$ in particular. Therefore, TNF- $\alpha$ protein levels in adipose tissue and muscle in rats as well as other animals have not been reported. In this study, we established a sensitive and specific sandwich EIA for mouse and rat TNF- $\alpha$ and measured 
$y=10.411+2.7833 \mathrm{e}-2 x \quad R^{\wedge} 2=0.951$

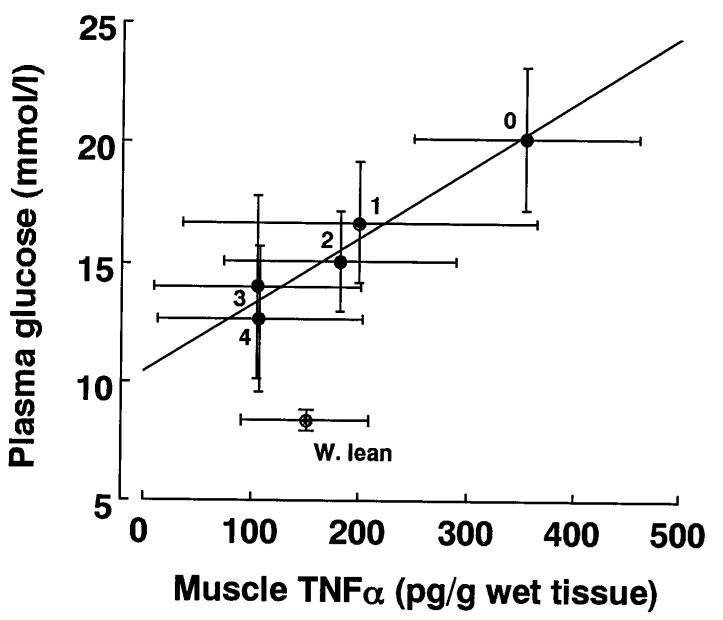

Fig. 4. Relationship between the muscle TNF- $\alpha$ level and plasma glucose/triglyceride level. Each point represents the mean \pm SD for each experimental group, and regression lines were drawn using data from fatty rats

TNF- $\alpha$ levels in plasma and skeletal muscle. In genetically obese and diabetic Wistar fatty rats, TNF- $\alpha$ levels in both plasma and skeletal muscle, which is a major target tissue of insulin, were significantly higher than those in lean rats. Moreover, administration of the insulin sensitizing agent pioglitazone time-dependently decreased plasma and muscle TNF- $\alpha$ levels followed by a decrease in plasma indicators of insulin resistance such as glucose, triglyceride and insulin. There were significant positive correlations between the muscle TNF- $\alpha$ level and the plasma glucose or triglyceride level among the fatty rat groups. Since TNF- $\alpha$ is known to be responsible for hyperglycaemia via inhibition of insulin receptor phosphorylation in muscle [9] and responsible for hyperlipidaemia [24] via inhibition of adipose lipoprotein lipase and/ or stimulation of hepatic lipogenesis [25], a change in muscle TNF- $\alpha$ production is one of the major causal factors for the alteration of insulin resistance-induced metabolic abnormalities.

Hofmann et al. [11] reported that the overexpression of mRNA of TNF- $\alpha$ and its receptors in adipose tissue of obese and diabetic $\mathrm{KKA}^{\mathrm{y}}$ mice could be partially suppressed by pioglitazone. More recently, they showed a possible intracellular mechanism for TNF$\alpha$-induced insulin resistance. Namely, that TNF- $\alpha$ induces phosphorylation of IRS-1 on the serine residue and converts IRS-1 into an inhibitor of IR tyrosine kinase. We have previously reported that the phosphorylation of tyrosine residues in IR or IRS-1 and the activation of phosphatidylinositol 3(PI3)-kinase in response to insulin are incomplete in skeletal muscle of Wistar fatty rats and that treatment with pioglitaz- $y=-6.7244+1.0374 x R^{\wedge} 2=0.904$

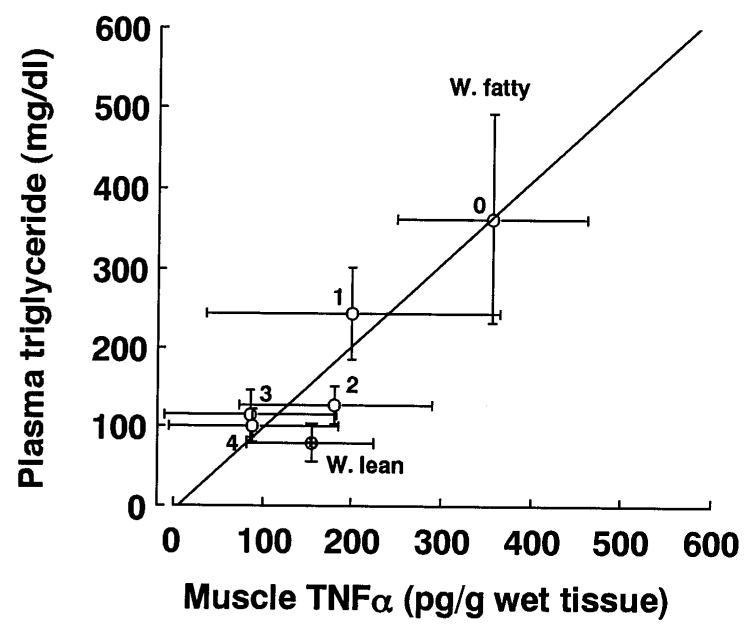

one increased insulin-stimulated tyrosine phosphorylated IR and IRS-1 levels and PI3-kinase activity [20]. Since muscle TNF- $\alpha$ level was normalized before plasma glucose level fell completely, the suppression of TNF- $\alpha$ expression in muscle and adipose tissue might be involved in the mechanism by which pioglitazone reduces insulin resistance. It is likely that subsequent reduction of TNF- $\alpha$ content in these tissues results in restoration of the muscle signal transduction system for insulin possibly via inhibition of serine phosphorylation of IRS-1.

It is reported that TNF- $\alpha$ mRNA is overexpressed in epididymal adipose tissue of diabetic $\mathrm{KKA}^{\mathrm{y}}$ mice [11]. Moreover, adipose tissue is present around muscles and between muscle fibers. TNF- $\alpha$ produced from those adipose tissues must affect adjoining muscles to induce insulin resistance in a paracrine fashion. Therefore, in parallel with this study, we also measured the TNF- $\alpha$ level in the adipose tissue of male Wistar fatty rats of 31 week of age. TNF- $\alpha$ level in this adipose tissue was $49.05 \pm 31.13 \mathrm{pg} / \mathrm{g}$ wet tissue (mean $\pm \mathrm{SD}, n=10$ ). Although many studies have shown the overexpression of TNF- $\alpha$ mRNA in adipose tissue during the development of obesity, TNF$\alpha$ protein level in adipose tissue was not as high as that in muscle (Fig. 3). It is also possible that a small amount of adipose tissue contaminated the muscle samples, but the contaminant was probably very small and thus produced less in the muscle sample. Therefore, the amount of adipose tissue TNF- $\alpha$ in this study was thought to be almost exclusive from that of muscle and the TNF- $\alpha$ level in muscle was important in insulin resistance. The importance of muscle TNF- $\alpha$ is also supported by the fact that diabetic patients with NIDDM overexpress TNF- $\alpha$ mRNA in muscle tissue [10] and adipose tissue $[7,8]$ and TNF$\alpha$ mRNA is also overexpressed in cultured muscle cells from insulin resistant and diabetic subjects [10]. Although pioglitazone is very effective in diabetic animals with NIDDM, it does not alter the plasma glu- 


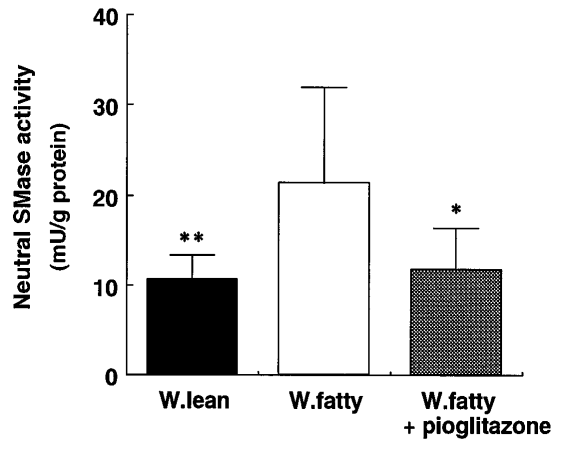

Fig.5. Effect of pioglitazone on neutral sphingomyelinase (SMase) activity in Wistar fatty rats. Pioglitazone was administered orally to 16 -week-old male Wistar fatty rats $(3 \mathrm{mg} / \mathrm{kg})$ for 4 days, as described in Methods. Data are mean \pm SD $(n=10)$. $* p<0.05$ and $* * p<0.01$ vs non-treated Wistar fatty rats

cose level in streptozotocin-diabetic rats or normal rats [16], that display neither TNF- $\alpha$ mRNA overexpression nor insulin resistance. Pioglitazone also did not affect the tyrosine phosphorylated IR and IRS-1 levels and PI3 kinase activity in Wistar lean rats [20]. These facts suggest that one of the anti-diabetic actions of pioglitazone is due to the improvement of glucose metabolism by the normalization of TNF- $\alpha$ production in muscle.

TNF- $\alpha$ has been demonstrated to induce sphingomyelin hydrolysis in HL-60 cells [26] and 3T3-L1 cells [27] in a time- and dose-dependent manner by the generation of phosphocholine and ceramide. It has been suggested that ceramide is an effector mediating the biological activities of TNF- $\alpha$ and that intracellular ceramide signalling down-regulates GLUT4 gene transcription in 3T3-L1 adipocytes [27]. In cultured rat skeletal muscle cells, TNF- $\alpha$ has been shown to block insulin-stimulated glycogen synthesis via ceramide release [28] and to blunt insulin's effect on mitogen-activated protein kinase (MAPK) activation by increasing dephosphorylation of MAPK kinase [29]. Therefore, we presumed that SMase plays a role in TNF- $\alpha$-induced insulin resistance. The activity of SMase in fatty rats was actually two times higher than that in lean rats and was decreased to the level in lean rats by treatment with pioglitazone. The degree of this change was similar to that in the level of muscle TNF- $\alpha$. These results suggest that elevation of the TNF- $\alpha$ level and the subsequent activation of neutral SMase are closely linked with insulin resistance. Since pioglitazone did not have inhibitory effects on neutral SMase in cell free systems (data was not shown), pioglitazone might exhibit its antidiabetic effect through the inhibition of TNF- $\alpha$ production. This process indicates that pioglitazone specifically enhances the phosphorylation of IR. We have previously reported that pioglitazone improves the insulin signalling defect in skeletal muscle from Wistar fatty rats [20].
Recent reports showed that thiazolidinedione derivatives are high affinity ligands for peroxisome proliferator-activated receptor $\gamma(\operatorname{PPAR} \gamma) 2$ [30]. $\operatorname{PPAR} \gamma 2$ is predominantly expressed in adipose tissue and is also expressed in skeletal muscle of mice [31]. In adipose tissue, PPAR $\gamma$ plays a role in the induction of adipocyte differentiation $[32,33]$. Therefore, it is possible that the insulin-sensitizing effect of pioglitazone starts from the activation of PPAR $\gamma 2$. Although the physiological role of muscle PPAR $\gamma 2$ is not known, we think that the activation of PPAR $\gamma 2$ in muscle by its endogenous ligand leads to maintaining the insulin sensitivity of these tissues. Since pioglitazone significantly decreased plasma glucose and triglyceride levels and the muscle TNF- $\alpha$ level in fatty rats within 2 days, the rapid decrease in TNF- $\alpha$ cannot be due to the suppression of differentiation of preadipocytes to adipocytes. The inhibition of TNF$\alpha$ production is probably due to some other effect of the PPAR $\gamma 2$-pioglitazone complex or pioglitazone alone. Further studies will be required to fully clarify the mechanism of the pioglitazone-induced reduction of TNF- $\alpha$.

It has been suggested that adipocyte-specific leptin production is up-regulated by humoral factors such as insulin and glucocorticoid [34] and is altered in response to starvation and refeeding [35]. Another study showed that treatment with the insulin-sensitizing agent troglitazone for 4 weeks decreased $o b$ gene expression in Zucker fatty rats and $d b / d b$ mice [36]. In our present study, the plasma leptin level did not change during the 4-day pioglitazone treatment period, although plasma TNF- $\alpha$ and other diabetic indices were lowered. Therefore, our findings suggest that leptin is not involved in the mechanism of action of pioglitazone and thiazolidine derivatives.

Thiazolidinedione derivatives have been reported to act not only in muscle and adipose tissue but also in the pancreatic beta cell, in which insulin secretion increased in Zucker fatty rats [37] or in isolated islets [38]. Thiazolidinedione derivatives are also known to act in liver to prevent glucose production [19] or to inhibit fatty acid oxidation [39]. Since PPAR $\gamma 2$ only very slightly or not at all exhibits in pancreas and liver, these effects probably depend on another pathway and do not relate to the suppression of TNF- $\alpha$ production. In these tissues, thiazolidinedione derivatives may directly affect IR. It has been reported that thiazolidinedione derivatives stimulate IR autophosphorylation and tyrosine kinase activity without changing in IR number [20] or directly affecting translocation of several protein kinase $\mathrm{C}$ isoforms [40]. In further studies, we need to point out mechanisms of the anti-diabetic effect which do not depend on PPAR $\gamma$ binding.

In conclusion, we have demonstrated that TNF- $\alpha$ is overproduced in genetically obese and diabetic $\mathrm{Wi}$ star fatty rats and that short-term administration of 
the insulin-sensitizing agent pioglitazone results in a reduction of the TNF- $\alpha$ level as well as neutral SMase activity in muscle. These results suggest an important role for muscle TNF- $\alpha$ in insulin resistance and provide new insights into our understanding of the mechanism of action of pioglitazone.

\section{References}

1. DeFronzo RA, Ferrannini E, Koivisto V (1983) New concepts in the pathogenesis and treatment of noninsulin-dependent diabetes mellitus. Am J Med 74 (Suppl 1A):52-81

2. Efendic S, Luft R, Wajngot A(1984) Aspects of the pathogenesis of type 2 diabetes. Endocr Rev 5: 395-410

3. Olefsky JM (1985) Pathogenesis of insulin resistance and hyperglycaemia in non-insulin-dependent diabetes mellitus. Am J Med 79 (Suppl 3B):1-7

4. Hotamisligil GS, Shargill NS, Spiegelman BM (1993) Adipose expression of tumor necrosis factor- $\alpha$ : direct role in obesity-linked insulin resistance. Science 259: 87-91

5. Hamann A, Benecke H, Le Marchand-Brustel Y, Susulic VS, Lowell BB, Flier JS (1995) Characterization of insulin resistance and NIDDM in transgenic mice with reduced brown fat. Diabetes 44: 1266-1273

6. Hotamisligil GS, Spiegelman BM (1994) Tumor necrosis factor- $\alpha$ : a key component of the obesity-diabetes link. Diabetes 43: 1271-1278

7. Hotamisligil GS, Arner P, Caro JF, Atkinson RL, Spiegelman BM (1995) Increased adipose tissue expression of tumor necrosis factor- $\alpha$ in human obesity and insulin resistance. J Clin Invest 95: 2409-2415

8. Kern PA, Saghizadeh M, Ong JM, Bosch RJ, Deem R, Simsolo RB (1995) The expression of tumor necrosis factor in human adipose tissue. Regulation by obesity, weight loss, and relationship to lipoprotein lipase. J Clin Invest 95: 2111-2119

9. Hotamisligil GS, Budavari A, Murray D, Spiegelman BM (1994) Reduced tyrosine kinase activity of the insulin receptor in obesity-diabetes. Central role of tumor necrosis factor- $\alpha$. J Clin Invest 94: 1543-1549

10. Saghizadeh M, Ong JM, Garvey WT, Henry RR, Kern PA (1996) The expression of TNF- $\alpha$ by human muscle. Relationship to insulin resistance. J Clin Invest 97: 11111116

11. Hofmann C, Lorenz K, Braithwaite SS et al. (1994) Altered gene expression for tumor necrosis factor- $\alpha$ and its receptors during drug and dietary modulation of insulin resistance. Endocrinology 134: 264-270

12. Haring HU, Mehnert H (1993) Pathogenesis of type 2 (noninsulin-dependent) diabetes mellitus: candidates for a signal transmitter defect causing insulin resistance of the skeletal muscle. Diabetologia 36: 176-182

13. Peraldi P, Hotamisligil GS, Buurman WA, White MF, Spiegelman, BM. (1996) Tumor necrosis factor (TNF)- $\alpha$ inhibits insulin signaling through stimulation of the p55 TNF receptor and activation of sphingomyelinase. J Biol Chem 271: 13018-13022

14. Liu J, Mathias S, Yang Z, Kolesnick RN (1994) Renaturation and tumor necrosis factor- $\alpha$ stimulation of a 97-kDa ceramide-activated protein kinase. J Biol Chem 269: 3047-3052

15. Hotamisligil GS, Peraldi P, Budavari A, Ellis R, White MF, Spiegelman BM (1996) IRS-1-mediated inhibition of insulin receptor tyrosine kinase activity in TNF- $\alpha$ - and obesity-induced insulin resistance. Science 271: 665-668
16. Ikeda H, Taketomi S, Sugiyama Y et al. (1990) Effects of pioglitazone on glucose and lipid metabolism in normal and insulin resistant animals. Arzneim Forsch Drug Res 40: $156-162$

17. Ikeda H, Shino A, Matsuo T, Iwatsuka H, Suzuoki Z (1981) A new genetically obese-hyperglycaemic rat (Wistar fatty). Diabetes 30: 1045-1050

18. Sugiyama Y, Taketomi S, Shimura Y, Ikeda H, Fujita T (1990) Effects of pioglitazone on glucose and lipid metabolism in Wistar fatty rats. Arzneim Forsch Drug Res 40: 263 267

19. Sugiyama Y, Shimura Y, Ikeda H (1990) Effects of pioglitazone on hepatic and peripheral insulin resistance in Wistar fatty rats. Arzneim Forsch Drug Res 40: 436-440

20. Hayakawa T, Shiraki T, Morimoto T, Shii K, Ikeda H (1996) Pioglitazone improves insulin signaling defects in skeletal muscle from Wistar fatty (fa/fa) rats. Biochem Biophysi Res Commun 223: 439-444

21. Murase K, Takeuchi R, Furukawa S, Furukawa Y, Hayashi K (1990) Highly sensitive enzyme immunoassay for $\beta$ nerve growth factor (NGF): a tool for measurement of NGF in rat serum. Biochem Int 22: 807-813

22. Gatt S, Dinur T, Barenholz Y (1978) A spectrophotometric method for determination of sphingomyelinase. Biochem Biophys Acta 530: 503-507

23. Poll TVD, Romijn JA, Endert E, Borm JJJ, Buller HR, Sauerwein HP (1991) Tumor necrosis factor mimics the metabolic response to acute infection in healthy humans. Am J Physiol 261:E457-E465

24. Pereira BJG, Shapiro L, King AJ, Falagas ME, Strom JA, Dinarello CA (1994) Plasma levels of IL-1 b, TNFa and their specific inhibitors in undialyzed chronic renal failure, CAPD and hemodialysis patients. Kidney International 45: 890-896

25. Zhang B, Berger J, Hu E et al. (1996) Negative regulation of peroxisome proliferator-activated receptor- $\gamma$ gene expression contributes to the antiadipogenic effects of tumor necrosis factor- $\alpha$. Mol Endocrinol 10: 1457-1466

26. Hannun YA, Bell RM (1993) The sphingomyelin cycle: a prototypic sphingolipid signaling pathway. Adv Lipid Res 25: $27-41$

27. Long SD, Pekala PH (1996) Lipid mediators of insulin resistance: ceramide signalling down-regulates GLUT4 gene transcription in 3T3-L1 adipocytes. Biochem J 319: 179-184

28. Begum N, Ragolia L (1995) Effect of tumor necrosis factor$\alpha$ on insulin action in cultured rat skeletal muscle cells. Endocrinology 137: 2441-2446

29. Begum N, Ragolia L, Srinivasan M (1996) Effect of tumor necrosis factor- $\alpha$ on insulin-stimulated mitogen-activated protein kinase cascade in cultured rat skeletal muscle cells. Eur J Biochem 238: 214-220

30. Lehmann JM, Moore LB, Smith-Oliver TA, Wilkison WO, Willson TM, Kliewer SA (1995) An antidiabetic thiazolidinedione is a high affinity ligand for peroxisome proliferator-activated receptor $\gamma(\operatorname{PPAR} \gamma)$. J Biol Chem 270: 12953-12956

31. Vidal-Puig A, Jimenez-Linan M, Lowell BB et al. (1996) Regulation of PPAR $\gamma$ gene expression by nutrition and obesity in rodents. J Clin Invest 97: 2553-2561

32. Chawla A, Schwarz EJ, Dimaculangan DD, Lazar MA (1994) Peroxisome proliferator-activated receptor (PPAR) $\gamma$ : adipose-predominant expression and induction early in adipocyte differentiation. Endocrinology 135: 798-800

33. Tontonoz P, Hu E, Graves RA, Budavari AI, Spiegelman $\mathrm{BM}$ (1994) mPPAR $\gamma 2$ : tissue-specific regulator of an adipocyte enhancer. Genes Dev 8: 1224-1234 
34. Frederich RC, Lollmann B, Hamann A et al. (1995) Expression of ob mRNA and its encoded protein in rodents. Impact of nutrition and obesity. J Clin Invest 96: 16581663

35. De Vos P, Saladin R, Auwerx J, Staels B (1995) Induction of ob gene expression by corticosteroids is accompanied by body weight loss and reduced food intake. J Biol Chem 270: $15958-15961$

36. Zhang B, Graziano MP, Doebber TW et al. (1996) Downregulation of the expression of the obese gene by an antidiabetic thiazolidinedione in Zucker diabetic fatty rats and $\mathrm{db} / \mathrm{db}$ mice. J Biol Chem 16: 9455-9459

37. Sreenan S, Sturis J, Pugh W, Burant CF, Polonsky KS (1996) Prevention of hyperglycaemia in the Zucker diabetic fatty rat by treatment with metformin or troglitazone. Am J Physiol 271:E742-E747

38. Masuda K, Okamoto Y, Tsuura Y et al. (1995) Effects of troglitazone (CS-045) on insulin secretion in isolated rat pancreatic islets and HIT cells: an insulinotropic mechanism distinct from glibenclamide. Diabetologia 38: 24-30

39. Fulgencio JP, Kohl C, Girard J, Pegorier JP (1996) Troglitazone inhibits fatty acid oxidation and esterification, and gluconeogenesis in isolated hepatocytes from starved rats. Diabetes 45: 1556-1562

40. Kellerer M, Kroder G, Tippmer S et al. (1994) Troglitazone prevents glucose-induced insulin resistance of insulin receptor in rat-1 fibroblasts. Diabetes 43: 447-453 